\title{
Islamic Education and Level of Character Internalization of Secondary School Students in Malaysia
}

\author{
Jawiah Dakir \\ Institute of Islam Hadhari, The National University of Malaysia \\ jawiah@ukm.edu.my \\ Mohd Yus of Hj Othman \\ Institute of Islam Hadhari, The National University of Malaysia \\ myho@ukm.edu.my
}

Ab. Halim Tamuri

Faculty of Education, The National University of Malaysia tamuri67@gmail.com

Zakaria Stapa

Institute of Islam Hadhari, The National University of Malaysia karia@ukm.edu.my

Shamsul Azhar Yahya

Institute of Islam Hadhari, The National University of Malaysia hjshamsul@ukm.edu.my

Siti Maheran Ismail @ Ibrahim

Doi:10.5901/mjss.2015.v6n4p602

\author{
Institute of Islam Hadhari, The National University of Malaysia
} maheran@ukm.edu.my

\section{Abstract}

Islamic Education in Malaysia is a structured system of education with a systematic curriculum and is supported by capable teaching staff who have undergone teacher's training at government-regulated institutions. Generally, this education system aspires to produce human capital which is holistic, competent and excellent in all aspects of humanity. Lately, however, there has been news displayed in the national newspaper concerning the deterioration in moral character of adolescents, despite the fact that they have undergone this system of education. This article shows the outcome of research on the effectiveness of the Islamic education system among secondary school students in Malaysia. This research is conducted using data collection methodology through questionnaire survey, interview and observation. Research findings show that Islamic education in Malaysia has a good effect on the character formation of students involved. Findings also show that a good level of Islamic knowledge has increased the level of character internalization of students. However, the influence of social environment has made a significant impact at an average level on the level of character internalisation of students.

Keywords: Islamic Education, Character Internalization, Secondary School, Student Character, Systematic Curriculum

\section{Introduction}

The Islamic Education System in Malaysia has been systematically and properly planned in terms of curriculum, implementation and teacher/ teaching staff training since independence. Competent teaching staff/ teachers are trained in government- monitored institutions. Among the objectives is to produce Muslims who are capable of practising Islamic knowledge learnt as a way of life, at once developing human capital for future generations. Effective development of this generation is important as the most important Malaysian human asset in the government's efforts to realize a progressive, excellent, glorious and distinctive nation.

Lately, however, the scenario and environment relating to youth character and morals have shown an increasingly worrisome decline. Misdemeanours or crimes, whether civil or shariah, have reached a level whereby it is shown almost daily in the mass media or electronic media. Hence, research on Islamic education in Malaysia is conducted to examine its effectiveness in human capital development. 
The purpose of this research is to identify the level of Islamic education of Muslim students in Malaysia and the extent of its effectiveness on the behaviour of students in developing themselves, physically and spiritually. In addition, this research also examines and identifies the Influence of the social environment as a separate variable in the formation of student behaviour in Malaysia.

\section{Issues of Character and Education in Malaysia}

Throughout the implementation of Islamic Education in schools, there have been certain shortcomings of which the most obvious is its lack of effectiveness on building student character (Asmawati 2003, Ministry of Education of Malaysia 1996, Zakaria et al. 1996 \& 1998). In order to overcome this, the curriculum of Islamic Education was formulated and Islamic Character Education was introduced as a major component in the subject of Islamic Education, replacing its old name, part on the Nature and Way of Life in Islam. Implementation of the part on Islamic Character Education commenced in the year 1998 and ended in the year 2000 (Asmawati 2003).

Later, the syllabus of Islamic Education was revised a second time because it was said that its curriculum, particularly character education, was ineffective as moral decline among Muslim youth was increasing (Director of Islamic Education and Morals Department in Asmawati 2003). Following this, Character Education again experienced substantial changes in terms of its syllabus and teaching approach (Asmawati 2003). This part was renamed as part on Islamic Character (Form 1 Islamic Education for Secondry Schools - KBSM 2004) and began to be implemented in stages in the year 2003 for Form 1 and Form 4, then fully by the year 2005 (Asmawati 2003).

Through the Curriculums of Primary School (KBSR) and the Curriculums of Secondry School (KBSM), character education exposure was not only focused on a part of Islamic Education, the Part on Islamic Character, but was actually applied or intertwined with the application of other subjects and co-curriculum activities in schools (Ministry of Education 1990). Even though it sometimes uses terms such as noble values or moral values, the objective is always to create a generation with noble values (Wan Hasmah 1993).

In-depth knowledge of the contents (Part on Islamic Character) at school level is very important to trainee teachers in order for them to equip themselves, while training, with a set of knowledge of the contents to teach it in its implementation at school. Moreover, trainee teachers have the opportunity to obtain books or related reference books to reinforce their knowledge.

In addition, knowledge of its contents help the teacher to connect the skills taught while in training with real application. Trainee teachers may also explore suitable teaching strategies with the contents they have mastered. Best of all is when the trainee teachers have managed to link the current character issues with the character contents they have mastered, and proceed to look for certain solutions. That said, it is significant in teacher training to sufficiently expose trainees to the contents of character education encompassing school level contents and even higher.

\section{Materials and Methods}

The research methodology is mixed quantitative and qualitative with survey method as the main research method. Questionnaires are used as instrument for data collection through random sampling for the representative population selected from among Muslim students of day secondary schools. In addition, data from qualitative sources which involve library sources, including examination of related documents and interviews of individuals are also analysed and identified to corroborate quantitative data and establish data triangulation. The purpose of this design is to obtain general information through a comprehensive collection from a population. Its purpose is to obtain information on the variables related to a phenomena without questioning why these variables exist. This instrument is effective in measuring a large population and multiple samples.

Population: This research population consists of lower forms 4 and 6 students of National Secondary Schools (SMK), Full Boarding Schools (SBP), Religious National Secondary Schools (SMKA) and Technical Secondary Schools (SMT) in Malaysia. This selection is based on the general premise that students have reached their puberty stage of maturity (age 15 years) which is set as the age to bear responsibility (Abdullah Nasih 1984). Students at this stage have also undergone the learning process through the Islamic Education Curriculum for at least 9 years in primary (KBSR) and secondary (KBSM) schools and are presumed to be able to assess themselves in the internalization aspect of Islamic teachings acquired through the Islamic Education curriculum of the national education system.

Sample: The total number of respondents for this research is 3240 , involving 540 students from each zone, which is 180 respondents ( 90 from SMK, 30 from SBP, 30 from SMKA and 30 from SMT) for each state. Several considerations are taken into account by the researcher in determining sample size. According to Cohen et al. (2000), a study which adopts random sampling technique for a heterogenous population basically needs a large sample size. In addition, 
research design also influences sample size. A study which adopts a survey method, requires a large sample, particularly if inferential statistical methods are used (Cohen et al. 2000; Ratnawati 2003). A large sample size also leads to a normal curve and conforms to the population values of a research (Cates 1990).

Sampling Method: The method used in selection of research sample is random probability sampling. It is used to ensure that each member has an equal chance of representing the population in this research (Ary et. al. 1990). By this method, the writer is also able to make statistical inferences from the population sample (Berenson 1992). Sample units are also randomly selected based on the zone system, namely:

a. North Zone (Kedah, Pulau Pinang and Perlis);

b. South Zone (Johor, Melaka and Negeri Sembilan);

c. East Zone (Kelantan, Terengganu and Pahang);

d. Central Zone (Perak, Selangor and Wilayah Persekutuan);

e. Sabah (Northern, South-eastern and South Zones); and

f. Sarawak ( Northern, Central and Southern Zones).

Research Instrument: Quantitative data collection uses a set of questionnaire which is divided into five parts, Part A: Demographic background (12 questions), Part B: Level of Islamic Knowledge (51 questions), Part C: Level of Character Internalization (42 questions), Part D: Implementation of Islamic Education in School (34 questions) and Part E: Influence of Social Environment (28 questions) as well as space for any suggestions. The questionnaire is constructed using Likert scale from 1 to 5. To determine the level of character internalization, the researcher categorises and interprets the scores into three levels as displayed in Table 1 below. Mean scores of 1.00 to 2.33 indicate a low level. Mean scores between 2.34 and 3.66 indicate average level. And mean scores of 3.67 to 5.00 indicate a high level.

Table 1. Interpretation of average scores (Likert Scale 5)

$\begin{array}{cc}\text { Average Score } & \text { Interpretation } \\ 1.00 \text { to } 2.33 & \text { Low } \\ 2.34 \text { to } 3.66 & \text { Average } \\ 3.67 \text { to } 5.00 & \text { High }\end{array}$

Source: Modified from Pallant (2001)

And the method of qualitative data collection is by using three sets of structured interview protocol inventories on selected individuals, namely, administrators, IPGM lecturers and Islamic Education teachers according to category of school type. These interviews are conducted based on the justifications of these individuals who head important national institutions, particularly, policy-makers for the advancement of Islamic education in this country.

Validation and Reliability of Instrument: A pilot study was carried out from $18^{\text {th }}$ to 22nd April 2011 to determine the reliability value of the questionnaire instrument used in this research, namely, Parts B, C, D and E. The pilot study involved 99 students who were taking the subject Islamic Education. They comprised of Form 4 students of different academic streams and were randomly selected from two schools in Selangor, one representing rural area, and the other representing urban area.

Determination of the reliability value of the research instrument was done by identifying the level of internal consistency for various items used in this research. Internal reliability is important to determine the internal consistency of various items in the instrument such as used in this research. To obtain the internal consistency value of instrument items, Alpha value based on Cronbach coefficient was used because the variables used in this research were noncategory in form. According to Cramer (1998), Alpha Cronbach value is a method of measuring the reliability value frequently used for non-category set of questionnaire. For the purpose of classification, the Alpha Cronbach coefficient used in this research has been classified according to the reliability classification index by Babbie (1992) such as in Table 2 below. Generally, many researchers suggest that usually an Alpha coefficient value which exceeds 0.8 shows a high level of reliability and may be accepted for an instrument (Cramer 1999; Aiken 2000; Zaidatun \& Mohd Salleh 2003).

The outcome of analysis for the reliability value of the research instrument used shows the results as stated in Table 2 below:

Table 2: Alpha Cronbach Reliability Coefficient Value

\begin{tabular}{clcc}
\hline Part of & Instrument & No. of items & Alpha value \\
\hline B & Level of Islamic Knowledge & 51 & 0.856 \\
C & Level of Character Internalization & 42 & 0.877 \\
D & Implementation of Islamic Education in School & 34 & 0.924 \\
E & Influence of Social Environment & 28 & 0.869 \\
\hline
\end{tabular}

Source: Pilot Questionnaire 2011 
Outcome analysis of reliability value for the instrument used in this research such as in Table 2 above shows that all the parts of the instrument have a high reliability level $(>0.8)$ and may be used for the actual research.

\section{Results}

For quantitative data, the analysis process is done through the computer using Predictive Analysis Software 18 (PASW 18). Prior to analysis, the respondents' answer scores for negative items are first recoded to give the real picture of the direction and magnitude of the answer scores for the item statements. As example, item B08 (A Muslim believes that all acts, good and bad, are not recorded by the Angels) in the Part, Level of Islamic Knowledge, is expressed in a statement which portrays negative behavior. The score obtained for the relevant item is recoded to portray the actual behavior of the respondent. The respondent who selects scale 1 (Strongly Disagree) actually has the highest level of Islamic knowledge (A Muslim believes that all acts, good and bad, are recorded by the Angels). And the respondent who selects scale 5 (Strongly Agree) actually has the lowest level of Islamic knowledge (A Muslim believes that all acts, good and bad, are NOT recorded by the Angels). Thus, a descriptive analysis of the mean scores in an accrued way portray the real value of a student's knowledge whereby the lowest mean score reflects the lowest level of Islamic knowledge, while the highest mean score reflects the highest level of knowledge.

Analysis of the research data is divided into two parts, namely descriptive analysis and inferential analysis between parametered variables used in this research. This division is to enable the research hypothesis to be tested, to answer research questions and thereby achieve specified research objectives.

As for quanlitative data, recorded data of semi-structured interviews on self-regulated learning strategy of Islamic Education are transcribed following the method of partial transcription. The result of this partial transcription is then analysed by identifying the main themes which emerge from the interview results and are categorized according to the original distribution. The result of this distribution is then descriptively analysed using frequency to portray the main themes used by the respondents in Islamic Education self-regulated learning strategy. The summary of the frequency analysis of the themes of Islamic education self-regulated learning strategy may be referred to in the Appendix.

The following Table displays the analysis findings of Character internalization levels of Muslim students (Ab Halim Tamuri et al 2012; Ab Halim Tamuri et al 2013). The questions presented are to view the levels of Ccharacter internalization of students while they are going about their daily routine.

Table 3: Frequency of answers to items on Character internalization levels

\begin{tabular}{|c|c|c|c|c|c|c|c|c|}
\hline \multirow{2}{*}{ No. } & \multirow{2}{*}{ Level Of Character Internalization } & \multicolumn{5}{|c|}{ Frequency And Percentage } & \multirow{2}{*}{ MIN } & \multirow{2}{*}{ Sp. } \\
\hline & & SDA & DA NS & & A & SA & & \\
\hline $\mathrm{C} 01$ & $\begin{array}{l}\text { I reflect and observe the signs of Allah's greatness in myself and } \\
\text { nature all the time. }\end{array}$ & $19(1 \%)$ & $28(1 \%)$ & $391(12 \%)$ & $1743(53 \%)$ & $1069(33 \%)$ & 4.17 & 0.71 \\
\hline $\mathrm{CO} 2$ & I pray and hope for Allah's love. & $12(0 \%)$ & $22(1 \%)$ & $154(5 \%)$ & $1205(37 \%)$ & $1862(57 \%)$ & 4.50 & 0.65 \\
\hline $\mathrm{CO3}$ & I constantly take care in every action I do for fear of Allah. & $11(0 \%)$ & $37(1 \%)$ & $407(12 \%)$ & $1494(46 \%)$ & $1303(40 \%)$ & 4.24 & 0.74 \\
\hline $\mathrm{CO} 4$ & I obey Islamic law even if I have to leave my favourite activities. & $48(1 \%)$ & $88(3 \%)$ & $625(19 \%)$ & $1459(45 \%)$ & $1030(32 \%)$ & 4.03 & 0.87 \\
\hline $\mathrm{CO5}^{*}$ & I perform daily prayers only to fill my daily routine. & $1450(44 \%)$ & $822(25 \%)$ & $666(20 \%)$ & $246(6 \%)$ & $62(2 \%)$ & 4.03 & 1.06 \\
\hline $\mathrm{CO6}^{*}$ & I depart from Islamic teaching if it does not suit my wants. & $2372(73 \%)$ & $569(17 \%)$ & $187(6 \%)$ & $78(2 \%)$ & $46(1 \%)$ & 4.58 & 0.82 \\
\hline $\mathrm{CO}^{*}$ & $\begin{array}{l}\text { I believe that there are forces other than Allah which may heal } \\
\text { human illnesses. }\end{array}$ & $2626(80 \%)$ & $413(13 \%)$ & $90(3 \%)$ & $42(1 \%)$ & $77(2 \%)$ & 4.68 & 0.80 \\
\hline $\cos$ & $\begin{array}{l}\text { I need to execute Allah's commands and stay away from what is } \\
\text { prohibited with an open heart. }\end{array}$ & $40(1 \%)$ & $17(0 \%)$ & $57(2 \%)$ & $732(22 \%)$ & $2412(74 \%)$ & 4.67 & 0.66 \\
\hline $\operatorname{cog}$ & I do not do things which may lead to fornication (zina). & $82(2 \%)$ & $121(4 \%)$ & $517(16 \%)$ & $1149(35 \%)$ & $1386(42 \%)$ & 4.12 & 0.97 \\
\hline $\mathrm{C} 10$ & I greet salam whenever I meet my teacher. & $8(0 \%)$ & $13(0 \%)$ & $119(4 \%)$ & $1191(36 \%)$ & $1927(59 \%)$ & 4.54 & 0.61 \\
\hline C11 & I greet salam whenever I meet my friends. & $26(1 \%)$ & $78(2 \%)$ & $617(19 \%)$ & $1558(49 \%)$ & $974(30 \%)$ & 4.04 & 0.81 \\
\hline $\mathrm{C} 12$ & I love to practise the Prophet's (pbuh) sunnah. & $12(0 \%)$ & $49(1 \%)$ & $538(16 \%)$ & $1694(52 \%)$ & $962(29 \%)$ & 4.09 & 0.74 \\
\hline $\mathrm{C} 13$ & I keep my five daily prayers ( solah) & $53(2 \%)$ & $95(3 \%)$ & $535(16 \%)$ & $1178(36 \%)$ & $1390(43 \%)$ & 4.15 & 0.91 \\
\hline $\mathrm{C} 14^{*}$ & I indulge in illicit sexual acts. & $2768(85 \%)$ & $282(9 \%)$ & $90(3 \%)$ & $52(2 \%)$ & $57(2 \%)$ & 4.74 & 0.74 \\
\hline $\mathrm{C} 15$ & $\begin{array}{l}\text { I constantly avert my sight from looking at women 's (for men) or } \\
\text { men's (for women) aurah (forbidden physique). }\end{array}$ & $143(4 \%)$ & $190(6 \%)$ & $703(22 \%)$ & $1278(39 \%)$ & $940(29 \%)$ & 3.82 & 1.05 \\
\hline $\mathrm{C} 16$ & I constantly believe in the existence of Angels. & $10(0 \%)$ & $10(0 \%)$ & $51(2 \%)$ & $570(17 \%)$ & $2615(80 \%)$ & 4.78 & 0.51 \\
\hline $\mathrm{C} 17$ & $\begin{array}{l}\text { I believe that all good and bad actions we do are recorded by } \\
\text { Angels assigned by Allah. }\end{array}$ & $13(0 \%)$ & $5(0 \%)$ & $13(0 \%)$ & $254(8 \%)$ & $2974(91 \%)$ & 4.89 & 0.40 \\
\hline $\mathrm{C} 18^{*}$ & I take something even if it does not belong to me. & $1702(52 \%)$ & $745(23 \%)$ & $528(16 \%)$ & $226(7 \%)$ & $58(2 \%)$ & 4.17 & 1.04 \\
\hline $\mathrm{C} 19^{*}$ & I speak of other's shame or bad without his or her knowledge. & $1163(36 \%)$ & $711(22 \%)$ & $767(23 \%)$ & $512(16 \%)$ & $100(3 \%)$ & 3.71 & 1.19 \\
\hline $\mathrm{C} 20$ & I repent straightaway when I commit a sin. & $34(1 \%)$ & $88(3 \%)$ & $675(21 \%)$ & $1452(44 \%)$ & $1005(31 \%)$ & 4.01 & 0.85 \\
\hline $\mathrm{C} 21$ & I believe in Satan's existence. & $54(2 \%)$ & $29(1 \%)$ & $154(5 \%)$ & $953(29 \%)$ & $2066(63 \%)$ & 4.52 & 0.77 \\
\hline $\mathrm{C} 22$ & I believe all bad whisperings come from Satan. & $38(1 \%)$ & $34(1 \%)$ & $132(4 \%)$ & $742(23 \%)$ & $2310(71 \%)$ & 4.61 & 0.72 \\
\hline $\mathrm{C} 23$ & Reciting al-Quran gives me peace of mind. & $5(0 \%)$ & $5(0 \%)$ & $35(1 \%)$ & $520(16 \%)$ & $2694(83 \%)$ & 4.81 & 0.45 \\
\hline $\mathrm{C} 24$ & I feel sad when I see al-Quran burnt or desecrated. & $36(1 \%)$ & $27(1 \%)$ & $52(2 \%)$ & $378(12 \%)$ & $2756(84 \%)$ & 4.78 & 0.62 \\
\hline $\mathrm{C} 25$ & $\begin{array}{l}\text { I prefer listening to the latest song beats compared to Quran } \\
\text { recitals. }\end{array}$ & $767(23 \%)$ & $564(17 \%)$ & $1106(34 \%)$ & $678(21 \%)$ & $137(4 \%)$ & 2.64 & 1.17 \\
\hline $\mathrm{C} 26^{*}$ & It is permissible NOT to follow teachings in al-Quran. & 2628(81\%) & $315(10 \%)$ & $135(4 \%)$ & $70(2 \%)$ & $101(3 \%)$ & 4.63 & 0.90 \\
\hline
\end{tabular}




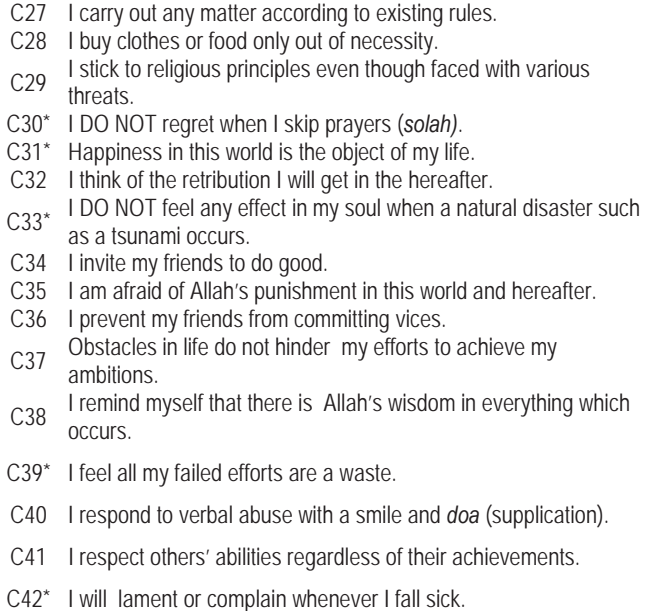

*negative items (recoded)

\begin{tabular}{cccccrc}
$63(2 \%)$ & $84(3 \%)$ & $625(19 \%)$ & $1659(51 \%)$ & $821(25 \%)$ & 3.95 & 0.85 \\
$26(1 \%)$ & $75(2 \%)$ & $496(15 \%)$ & $1615(49 \%)$ & $1043(\%)$ & 4.10 & 0.79 \\
$41(1 \%)$ & $38(2 \%)$ & $255(8 \%)$ & $1422(44 \%)$ & $1496(46 \%)$ & 4.32 & 0.77 \\
$1914(59 \%)$ & $626(19 \%)$ & $487(15 \%)$ & $156(5 \%)$ & $70(2 \%)$ & 4.28 & 1.02 \\
$957(\%)$ & $609(\%)$ & $996(\%)$ & $415(\%)$ & $273(\%)$ & 3.48 & 1.26 \\
$45(1 \%)$ & $31(1 \%)$ & $105(3 \%)$ & $1085(33 \%)$ & $1981(61 \%)$ & 4.51 & 0.73 \\
$1904(58 \%)$ & $728(22 \%)$ & $384(12 \%)$ & $130(4 \%)$ & $109(3 \%)$ & 4.29 & 1.04 \\
$19(1 \%)$ & $26(1 \%)$ & $268(8 \%)$ & $1632(50 \%)$ & $1310(40 \%)$ & 4.29 & 0.70 \\
$9(0 \%)$ & $7(0 \%)$ & $23(1 \%)$ & $517(16 \%)$ & $2695(83 \%)$ & 4.81 & 0.46 \\
$24(1 \%)$ & $45(1 \%)$ & $470(14 \%)$ & $1447(44 \%)$ & $1266(39 \%)$ & 4.19 & 0.78 \\
$21(\%)$ & $25(\%)$ & $186(\%)$ & $1248(\%)$ & $1770(\%)$ & 4.45 & 0.70 \\
$15(0 \%)$ & $15(0 \%)$ & $57(0 \%)$ & $693(21 \%)$ & $2468(76 \%)$ & 4.72 & 0.56 \\
$1314(40 \%)$ & $735(22 \%)$ & $806(25 \%)$ & $263(8 \%)$ & $130(4 \%)$ & 3.87 & 1.15 \\
$95(3 \%)$ & $167(5 \%)$ & $834(26 \%)$ & $1304(40 \%)$ & $851(26 \%)$ & 3.81 & 0.98 \\
$14(0 \%)$ & $30(1 \%)$ & $180(5 \%)$ & $1534(47 \%)$ & $1490(46 \%)$ & 4.37 & 0.67 \\
$934(29 \%)$ & $836(26 \%)$ & $932(29 \%)$ & $461(14 \%)$ & $87(3 \%)$ & 3.64 & 1.12 \\
Overall Total & & & & & 4.26 & 0.36 \\
\hline
\end{tabular}

The analysis findings above display the levels of character internalization in Muslim students. The questions presented are to view the levels of Character internalization in students while going about their daily routine. On the whole, only two items are at average level, namely, item C25 "I prefer to listen to the latest song beats compared to Quran recitals" $(\mathrm{M}=2.64, \mathrm{Sp} .=1.17)$ and $\mathrm{C} 42$ "I will lament or complain whenever I fall sick" $(\mathrm{M}=3.64, \mathrm{Sp} .=1.12)$. And 40 other items are at a high level. Item C35 "I am afraid of Allah's punishment in this world and hereafter" (M=4.81, Sp. $=0.46)$ is recorded as the item with the highest mean value. Research findings also show that the overall mean for the levels of Character internalization is $4.26(\mathrm{Sp} .=0.36)$.

\section{Inferential Findings}

In this part, the researcher presents inferential analysis findings regarding Islamic knowledge, Character internalization, Implementation of Islamic Education in school as well as the Influence of social environment. The analysis used are Independent Samples T-Test, One-way ANOVA test as well as Pearson Correlation. Independent Samples t-Test is used to see the level of difference between 2 variables. One-way ANOVA test is used to look at the difference between more than 2 variables. And Pearson Correlation is to see the correlation between 2 variables.

Findings of the t-test on variables gender, form, hostel, free TV broadcast, ASTRO, internet, mobile phone, PC/iPAD/ laptop, facebook, twitter and Blog are as in the following tables:

\subsection{Gender}

Table 4: t-test differences in level of character internalization according to Gender

\begin{tabular}{cccccccc}
\hline Variable & Gender & $\mathbf{N}$ & $\mathbf{M}$ & Sp. & Dk & Value of $\mathbf{t}$ & Value of $\mathbf{p}$ \\
\hline \multirow{2}{*}{ Level of Character internalization } & Male & 1486 & 4.21 & 0.38 & \multirow{2}{*}{2934.67} & \multirow{2}{*}{-7.910} & \multirow{2}{*}{$000^{*}$} \\
\cline { 3 - 7 } & Female & 1770 & 4.31 & 0.33 & & & \\
\hline
\end{tabular}

Source: Questionnaire 2011

Table 4 shows t-test results on the level of respondents' Character internalization according to gender. Findings show that there is a significant difference between male and female respondents ( $t(2934.67)=-7.910, p=0.000)$. Thus, research results reflect that the scores of Character internalization for female respondents are better than for male respondents.

\subsection{Place of Residence}

Table 5: t-test differences in levels of Character internalization according to place of residence

\begin{tabular}{cccccccc}
\hline Variable & Hostel & $\mathbf{N}$ & $\mathbf{M}$ & Sp. & Dk & Value of $\mathbf{t}$ & Value of $\mathbf{p}$ \\
\hline \multirow{2}{*}{ Level of character internalization } & Yes & 1624 & 4.26 & 0.35 & \multirow{2}{*}{3245} & \multirow{2}{*}{0.069} & \multirow{2}{*}{.945} \\
& No & 1622 & 4.26 & 0.36 & & \\
\hline
\end{tabular}

Source: Questionnaire 2011 
t-test results on levels of Character internalization of respondents according to place of residence shows no significant difference between respondents who stay in hostels and who live at home $\left(\mathrm{t}_{(3245)}=-0.069, p=0.945\right)$. thus, research results reflect that the level of Character internalization of respondents who stay in hostels is the same as the level of those respondents who live at home.

\subsection{Free TV Broadcast}

Table 6: $\mathrm{t}$ - test on differences in levels of Character internalization according to possession of free TV broadcast

\begin{tabular}{rcrrrrrr}
\hline Variable & Free TV broadcast & $\mathbf{N}$ & $\mathbf{M}$ & $\mathbf{S p}$. & Dk & Value of $\mathbf{t}$ & Value of $\mathbf{p}$ \\
\hline \multirow{2}{*}{ Level of Character internalization } & Possess & 3017 & 4.26 & 0.35 & 3237 & 0.349 & .727 \\
\cline { 2 - 7 } & Do Not Possess & 222 & 4.25 & 0.39 & & & \\
\hline
\end{tabular}

Source: Questionnaire2011

The researcher finds from Table 7 above that there is no significant difference in levels of Character internalization between respondents who possess free TV broadcast and those who do not ( $t(3237)=0.349, p=0.727)$. Thus, the research results show that the levels of Character internalization is the same whether the respondents possess free TV broadcast or not.

\subsection{ASTRO}

Table 7: t-test on the differences in level of Character internalization according to possession of ASTRO broadcast

\begin{tabular}{cccccccc}
\hline Variable & ASTRO & $\mathbf{N}$ & $\mathbf{M}$ & $\mathbf{S p}$. & Dk & Value of $\mathbf{t}$ & Value of $\mathbf{p}$ \\
\hline \multirow{2}{*}{ Level of Character Internalization } & Possess & 1984 & 4.26 & 0.36 & \multirow{2}{*}{3234} & \multirow{2}{*}{-0.236} & \multirow{2}{*}{.813} \\
\cline { 2 - 7 } & Do Not possess & 1252 & 4.26 & 0.35 & & & \\
\hline
\end{tabular}

Source: Questionnaire 2011

Table 8 shows the t-test results on the difference in levels of Character internationalization of respondents according to whether they possess ASTRO TV broadcast. Findings show that there is no significant difference between respondents who possess ASTRO TV broadcast or those who do not $(\mathrm{t}(3234)=-0.236, p=0.813)$. Thus, research results reflect that levels of Character internalization of respondents who possess ASTRO TV broadcast is the same as of respondents who do not so possess.

\subsection{Internet}

Table 8: t-test on the difference in levels of Character internalization according to possession of internet

\begin{tabular}{cccccccc}
\hline Variable & Internet & $\mathbf{N}$ & $\mathbf{M}$ & $\mathrm{Sp}$. & $\mathrm{Dk}$ & Value of $\mathrm{t}$ & Value of $\mathrm{p}$ \\
\hline \multirow{2}{*}{ Level of Character internalization } & Possess & 2169 & 4.27 & 0.35 & \multirow{2}{*}{3236} & \multirow{2}{*}{1.622} & \multirow{2}{*}{105} \\
& Do Not Possess & 1069 & 4.24 & 0.36 & & & \\
\hline
\end{tabular}

Source: Questionnaire 2011

t-test results on the levels of Character internalization of respondents who possess internet show that there is no significant difference between respondents who possess internet and thse who do not $\left(t{ }_{(3236)}=1.622, p=0.105\right)$. Thus, research results reflect that the level of Character internalization in respondents who possess internet is the same as of those who do not.

\subsection{Mobile Phone}

Table 9: t-test on differences in levels of character internalization according to possession of mobile phone

\begin{tabular}{cccccccc}
\hline Variable & Mobile Phone & $\mathbf{N}$ & $\mathbf{M}$ & $\mathbf{S p}$. & Dk & Value of $\mathbf{t}$ & Value of $\mathbf{p}$ \\
\hline \multirow{2}{*}{ Level of Character internalization } & Possess & 2808 & 4.26 & 0.35 & \multirow{2}{*}{3237} & \multirow{2}{*}{-0.085} & \multirow{2}{*}{.932} \\
\cline { 2 - 7 } & Do Not Possess & 431 & 4.26 & 0.38 & & \\
\hline
\end{tabular}

Source: Questionnaire 2011

Table 10 shows the t-test results on the differences in the level of Character internalization of respondents according to 
possession of mobile phone or not. Hypothesis $\mathrm{Ho} 31$ is accepted in view of there being no significant difference between respondents who possess a mobile phone and those who do not $\left(t{ }_{(3237)}=-0.085, p=0.932\right)$. Thus, research results reflect that the level of Character internalization in respondents who possess a mobile phone is the same as of those who do not so possess.

\subsection{PC/iPAD/Laptop Computer}

Table 10: t-test on differences in the level of Character internationlization according to possession of PC/iPAD/Laptop

\begin{tabular}{|c|c|c|c|c|c|c|c|}
\hline Variable & PC/iPAD/ Laptop & $\mathrm{N}$ & $M$ & Sp. & Dk & Value of $t$ & Value of $p$ \\
\hline $\begin{array}{c}\text { Level of } \\
\text { Character Internalization }\end{array}$ & $\begin{array}{c}\text { Possess } \\
\text { Do Not Possess }\end{array}$ & $\begin{array}{l}2004 \\
1234\end{array}$ & $\begin{array}{l}4.26 \\
4.26\end{array}$ & $\begin{array}{l}0.35 \\
0.36\end{array}$ & 3236 & 0.455 & 649 \\
\hline
\end{tabular}

Source: Questionnaire 2011

Findings of Table 10 above show t-test results on the level of Character internalization of respondents according to whether they possess PC/iPAD/Laptop Computer or not. Findings show that there is no significant difference between those who possess it and those who do not so possess $(\mathrm{t}(3236)=0.455, p=0.649)$. Thus, research results reflect that the level of Character internalization between those who possess PC/iPAD/Laptop Computer and those who do not is the same.

\subsection{Facebook}

Table 11: t-test on the differences in levels of Character internalization according to possession of Facebook account

\begin{tabular}{|c|c|c|c|c|c|c|c|}
\hline Variable & Facebook & $\mathbf{N}$ & M & Sp. & Dk & Value of $t$ & Value of $p$ \\
\hline Level of Character internalization & Possess Do Not Possess & $\begin{array}{c}2747 \\
477\end{array}$ & $\begin{array}{l}4.26 \\
4.26\end{array}$ & $\begin{array}{l}0.35 \\
0.37\end{array}$ & 3222 & 0.539 & .590 \\
\hline
\end{tabular}

Source: Questionnaire 2011

t-test results of the levels of Character internalization in respondents according to possession of Facebook account shows that there is no significant difference between respondents who possess Facebook account and those who do not $\left(\mathrm{t}{ }_{(3222)}=0.539, \mathrm{p}=0.590\right)$. Thus, hypothesis $\mathrm{H}_{0} 42$ is accepted because research results reflect the same levels of Character internalization for respondents who possess Facebook account and those who do not.

\subsection{Twitter}

Table 12: t-test on the differences in level of Character internalization according to possession of Twitter account

\begin{tabular}{cccccccc}
\hline Variable & Twitter & $\mathbf{N}$ & $\mathbf{M}$ & $\mathbf{S p}$ & $\mathbf{D k}$ & Value of $\mathbf{t}$ & Value of $\mathbf{p}$ \\
\hline \multirow{2}{*}{ Level of Character Internalization } & Possess & 555 & 4.29 & 0.36 & \multirow{2}{*}{3217} & \multirow{2}{*}{1.930} & \multirow{2}{*}{054} \\
\cline { 2 - 7 } & Do Not Possess & 2664 & 4.25 & 0.36 & & \\
\hline
\end{tabular}

Source: Questionnaire 2011

Based on the table above, there is no significant difference in levels of Character internalization between respondents who possess Twitter account and those who do not $\left(t_{(3217)}=1.930, p=0.054\right)$. Thus, it can be said that the level of Character internalization for respondents who possess twitter account and those who do not is the same.

\subsection{Blog}

Table 13: t-test on the differences in levels of Character internalization according to possession of blog

Source: Questionnaire 2011

\begin{tabular}{|c|c|c|c|c|c|c|c|}
\hline Variable & Blog & $\mathbf{N}$ & M & Sp. & Dk & Value of $t$ & Value of $p$ \\
\hline Level of Character Internalization & $\begin{array}{c}\text { Possess } \\
\text { Do Not Possess }\end{array}$ & $\begin{array}{r}629 \\
2591\end{array}$ & $\begin{array}{l}4.29 \\
4.25\end{array}$ & $\begin{array}{l}0.36 \\
0.35\end{array}$ & 3218 & 2.073 & $.038^{*}$ \\
\hline
\end{tabular}

Table 13 shows the t-test results on the differences in levels of Character internalization in respondents according to possession of blog. Findings show that there is a significant difference between respondents who possess blog and those who do not $(\mathrm{t}(3218)=2.073, p=0.038)$. Thus, research results reflect that the level of Character internalization in 
respondents who possess blog is better than those who do not possess it.

\section{One-way ANOVA}

This part presents findings of t-test analysis conducted on variables of zone, school type and examination results of Lower Form Examination (PMR).

Table 14: ANOVA on differences in level of Character internalization according to zone

\begin{tabular}{ccccccc}
\hline Variable & & JKD & DK & MKD & F & Sig \\
\hline \multirow{3}{*}{ Level of Character internalization } & Intergroup & 5.525 & 5 & 1.105 & & \\
& Intragroup & 410.698 & 3256 & .126 & 8.760 & $.000^{*}$ \\
& Total & 416.223 & 3261 & .126 & & \\
\hline
\end{tabular}

Source: Questionnaire 2011

Results of One-way Variance Analysis such as displayed in the Table above show that there is a significant difference $(F=8.760$, Sig. $=.000)$ in levels of Character internalization among respondents according to zone. By this, hypothesis Ho57 is refuted. Further, a post-hoc LSD test is conducted to identify the differences in mean scores of levels of Character internalization according to zone. The test results are displayed in the Table below:

\subsection{Zone}

Table 15: LSD on Differences in Character internalization according to zone

\begin{tabular}{ccccccccc}
\hline Zone & N & Mean & North & Central & South & East & Sabah & Sarawak \\
\hline North & 550 & 4.29 & & $.005^{*}$ & $.012^{*}$ & $.043^{*}$ & .404 & $.000^{*}$ \\
Central & 539 & 4.23 & .005 & & .751 & $.000^{\star}$ & .051 & .423 \\
South & 567 & 4.24 & .012 & .751 & & $.000^{\star}$ & .097 & .262 \\
East & 570 & 4.33 & .043 & .000 & .000 & & $.004^{*}$ & $.000^{\star}$ \\
Sabah & 538 & 4.27 & .404 & .051 & .097 & .004 & & $.007^{\star}$ \\
Sarawak & 498 & 4.21 & .000 & .423 & .262 & .000 & .007 & \\
\hline
\end{tabular}

* Significance at level $p<0.05$

Source: Questionnaire 2011

The results of post-hoc LSD test conducted to identify the differences in levels of Character internalization in respondents according to zone as in the Table above show significant differences in mean scores between North Zone and Central Zone (Sig.=.005), South Zone (Sig.=.012), East Zone (Sig.=.043) and Sarawak (Sig.=.000); Central Zone and East Zone Timur (Sig.=.000); South Zone and East Zone (Sig.=.000); East Zone and Sabah (Sig.=.004) and Sarawak (Sig.=.000); and between Sabah and Sarawak (Sig.=.007). These results also show no difference between North Zone and Sabah (Sig.=.404); Central Zone and South Zone (Sig.=.751), Sabah (Sig.=.051) and Sarawak (Sig.=.423); dan South Zone and Sabah (Sig.=.097) and Sarawak (Sig.=.262).

\subsection{School Type}

Table 16: ANOVA differences in level of Character internalization according to school type

\begin{tabular}{ccccccc}
\hline Variable & & JKD & DK & MKD & F & Sig \\
\hline \multirow{3}{*}{ Level of Character internalization } & Intergroup & 3.230 & 3 & 1.077 & & \\
& Intragroup & 412.993 & 3258 & .127 & 8.492 & \multirow{2}{*}{$.000^{*}$} \\
& Total & 416.223 & 3261 & .127 & & \\
\hline
\end{tabular}

Source: Questionnaire 2011

The results of One-way Variance Analysis such as displayed in the table above show significant difference in the level of Character internalization ( $F=8.492$, Sig.=.000) according to school type. By this, hypothesis Ho62 is refuted. Further, a post-hoc LSD test conducted to identify differences in levels of Character internalization according to school type. Findings of the test are shown as in the Table below: 
Table 17: LSD differences in levels of Character internalization according to school type

\begin{tabular}{ccccccc}
\hline Type & N & Mean & SMK & SMKA & SMT & SBP \\
\hline SMK & 1621 & 4.26 & & $.038^{*}$ & $.004^{*}$ & $.009^{\star}$ \\
SMKA & 594 & 4.29 & $.038^{\star}$ & & $.000^{\star}$ & .580 \\
SMT & 542 & 4.21 & $.004^{*}$ & $.000^{*}$ & & $.000^{\star}$ \\
SBP & 505 & 4.30 & $.009^{\star}$ & .580 & $.000^{\star}$ & \\
\hline
\end{tabular}

*Significance at level $p<0.05$

Source: Questionnaire 2011

Results of a post-hoc LSD test conducted to identify differences in levels of Character internalization in respondents according to school type as displayed in the Table above show significant differences in levels of Character internalization between SMK and SMKA (Sig.=.038), SMT (Sig.=.004) and SBP (Sig.=. 009); SMKA and SMK (Sig.=.038) and SMT (Sig.=.000); SMT and SMK (Sig.=.004), SMKA (Sig.=.000) and SBP (Sig.=.000); as well as between SBP and SMK (Sig.=.009) and SMT (Sig.=.000). Test results also show no difference between SMKA and SBP (Sig.=.508); as well as between SBP and SMKA (Sig.=.508).

\subsection{Lower Form Examination (PMR) Achievement}

Table 18: ANOVA differences in levels of Character internalization according to PMR Achievement

\begin{tabular}{ccccccc}
\hline Variable & & JKD & DK & MKD & F & Sig \\
\hline \multirow{3}{*}{ Level of Character internalization } & Intergroup & 11.759 & 4 & 2.940 & 23.939 & $.000^{\star}$ \\
& Intragroup & 388.546 & 3164 & .123 & & \\
& Total & 400.305 & 3168 & & & \\
\hline
\end{tabular}

Source: Questionnaire 2011

Results of One-way Variance Analysis such as displayed in the Table above show there is a significant difference in levels of Islamic knowledge ( $\mathrm{F}=23.939$, Sig. $=.000)$ according to PMR achievement. By this, Ho67 is refuted. Further, post-hoc LSD test conducted to identify differences in levels of Character internalization according to PMR achievement. The test results are displayed as in the Table below:

Table 19: LSD on differences in levels of Character internalization according to PMR achievement

\begin{tabular}{cccccccc}
\hline PMR & N & Mean & A & B & C & D & E \\
\hline A & 1854 & 4.29 & & $.011^{*}$ & $.000^{*}$ & $.000^{*}$ & $.000^{*}$ \\
B & 932 & 4.26 & $.011^{*}$ & & $.000^{*}$ & $.000^{*}$ & $.000^{*}$ \\
C & 313 & 4.15 & $.000^{*}$ & $.000^{*}$ & & $.001^{*}$ & $.002^{*}$ \\
D & 67 & 4.00 & $.000^{*}$ & $.000^{*}$ & $.001^{*}$ & & $.019^{*}$ \\
E & 3 & 3.51 & $.000^{*}$ & $.000^{*}$ & $.002^{*}$ & $.019^{*}$ & \\
\hline
\end{tabular}

*Significant at level $p<0.05$

Source: Questionnaire 2011

Results of post-hoc LSD test conducted to identify differences in Character internalization in respondents according to PMR achievement as in the Table above show that there is a significant difference between students who obtain grade $A$ and grade B (Sig.=.011), grade C (Sig.=.000) grade D (Sig.=.000) and grade E (Sig.=.000); students who obtain grade B and grade A (Sig.=.011), grade C (Sig.=.000), grade D (Sig.=.000) and grade E (Sig.=. 000); students who obtain grade $C$ and grade A (Sig.=.000), grade B (Sig.=.000) grade D (Sig.=.001) and grade E (Sig.=.001); students who obtain grade D and grade A (Sig.=.000), grade B (Sig.=.000) grade C (Sig.=.001) and grade E (Sig.=.019); as well as students who obtain grade E and grade A (Sig.=.000), grade B (Sig.=.000) grade C (Sig.=.002) and grade D (Sig.=.019).

\section{Pearson Correlation}

Pearson Correlation is conducted to view the interrelation of variables to study the effectiveness of Islamic Education. The interpretation of correlation value $(r)$ is conducted using the interpretation method by Julie Pallant (2007). According to Pallant, a value of $r=0.10$ to 0.29 (positive or negative) shows a low correlation between two variables. A value of $r$ $=0.30$ to 0.69 (positive and negatiive) shows an average correlation. And value of $r=0.70$ to 1.00 (positive and negative) shows a high correlation (see Table 4.325). 
Table 20: Interpretation of Correlation Coefficient Value

Source: Julie Pallant (2007)

\begin{tabular}{ccc}
\hline No. & Correlation Coefficient & Strength of correlation \\
\hline 1. & $\pm 0.70-1.00$ & High /Strong \\
2. & $\pm 0.30-0.69$ & Average \\
3. & $\pm 0.00-0.29$ & Low \\
\hline
\end{tabular}

Table 21: Correlation between research domains

\begin{tabular}{lcc}
\hline Variable & R & Sig. \\
\hline Level of Islamic Knowledge * Level of Character internalization & .445 & .000 \\
Implementation of Islamic Education in School * Level of Islamic Knowledge & .543 & .000 \\
Influence of Social Environment * Level of Islamic Knowledge & .447 & .000 \\
Implementation of Islamic Education in School * Level of Character Internalization & .740 & .000 \\
Influence of Social Environment * Level of Character Internalization & .510 & .000 \\
Influence of Social Environment * Implementation of Islamic Education in School & .613 & .000 \\
\hline
\end{tabular}

*Significance at level $p<0.01$

Source: Questionnaire 2011

Analysis of Pearson Correlation is conducted to ascertain correlation between the main research domains. Findings show there is an average correlation between 5 variables, namely level of Islamic knowledge and level of Character internalization ( $r=.445$, sig.=.000), Implementation of Islamic Education in school and Level of Islamic knowledge ( $r=.543$, sig.=.000), Influence of social environment and level of Islamic knowledge ( $r=.447$, sig.=.000), Influence of social environment and level of Character internalization ( $r=.510$, sig.=.000), as well as Influence of social environment and Implementation of Islamic Education in school $(\mathrm{r}=.613$, sig.=.000). Correlation analysis also shows a high correlation between Islamic Education in school and Level of Character internalization ( $r=.740$, sig. $=.000$ ). On the whole, analysis of these correlations shows a strong correlation among all main domains of this research. By this, hyothesis Ho71 is refuted.

Table 22: Correlation between variable Level of Islamic knowledge and Level of Character internalization

\begin{tabular}{lcc}
\hline Variable & R & Sig. \\
\hline Aqidah * Level of Character internalization & .352 & .000 \\
Tilawah al-Quran and Hadith * Level of Character internalization & .362 & .000 \\
Ibadah * Level of Character internalization & .308 & .000 \\
Seerah and Islamic Civilization * Level of Character internalization & .350 & .000 \\
Islamic Culture and Character * Level of Character internalization & .430 & .000 \\
Level of Islamic Knowledge * Level of Character internalization & .445 & .000 \\
\hline
\end{tabular}

*Significance at level $p<0.01$

Source: Questionnaire 2011

The above Table shows the results of Pearson Correalation analysis conducted to ascertain correlation between variables Level of Islamic Knowledge and Level of Character internalization. Findings show that there is an average correlation between all variables. Correlation between Islamic culture and character and level of Character internalization $(r=.430$, sig. $=.000)$ records the highest correlation value, followed by variables Tilawah al-Quran and hadith and level of Character internalization ( $r=.362$, sig.=.000), Aqidah (creeds) and Level of Character internalization ( $r=.352$, sig. $=.000$ ), History and Islamic Civllization and Level of Character internalization ( $r=.350$, sig.=.000), and finally between Ibadah and Level of Character internalization ( $r=.308$, sig.=.000). On the whole, analysis of correlation shows a strong significant correlation between Level of Islamic knowledge and Level of Character internalization ( $r=.445$, sig.=.000). This shows that a good level of Islamic knowledge is able to increase the level of Character internalization of students. By this, Ho72 is refuted. 
Table 23: Correlation between variable Influence of Social Environment and level of Character internalization

\begin{tabular}{lcc}
\hline Variable & R & Sig. \\
\hline Influence of Parents * Level of Character internalization & .364 & .000 \\
Influence of Teachers * Level of Character internalization & .477 & .000 \\
Influence of Friends * Level of Character internalization & .305 & .000 \\
Influence of Artistes * Level of Character internalization & .118 & .000 \\
Influence of School Environment * Level of Character internalization & .314 & .000 \\
Influence of Community * Level of Character internalization & .318 & .000 \\
Influence of Laws * Level of Character internalization & .330 & .000 \\
Influence of Social Environment * Level of Character internalization & .510 & .000 \\
\hline
\end{tabular}

*Significance at level $p<0.01$

Source: Questionnaire 2011

The above Table shows analysis findings of One-way ANOVA conducted to ascertain the correlation between variable Influence of Social Environment and Level of Character internalization. Findings show that hypothesis Ho76 is refuted. This is because on the whole the Influence of Social Environment has a significant impact at an average level on the level of Character internalization $(r=.510, \mathrm{sig} .=.000)$. From the findings in the above Table, only one variable is found to be at $a$ low level, namely, Influence of artistes ( $r=.118$, sig.=.000). This shows that artistes have a low influence on the building of youth character. Meanwhile, Islamic Education teachers $(r=.477$, sig. $=.000)$ are seen as having a very high influence on the building of youth character. The Influence of Parents ( $r=.364$, sig. $=.000)$, the law $(r=.330$, sig. $=.000)$, the community $(\mathrm{r}=.318$, sig.=.000), the school environment $(\mathrm{r}=.314$, sig. $=.000)$ and friends $(\mathrm{r}=.305, \mathrm{sig} .=.000)$ are also seen as having an effect on the level of Character internalization of respondents.

Table 24: Correlation between variable Influence of Social Environment and Implementation of Islamic Educattion in School

\begin{tabular}{lcc}
\hline Variable & $\mathrm{r}$ & Sig. \\
\hline Influence of Parents * Implementation of Islamic Education in School & .425 & .000 \\
Influence of Teachers * Implementation of Islamic Education In School & .576 & .000 \\
Influence of Friends * Implementation of Islamic Education in School & .353 & .000 \\
Influence of Artistes * Implementation of Islamic Education in School & .119 & .000 \\
Influence of School Environment * Implementation of Islamic Education in School & .406 & .000 \\
Influence of Community * Implementation of Islamic Education in School & .394 & .000 \\
Influence of Laws * Implementation of Islamic Education in School & .398 & .000 \\
Influence of Social Environment * Implementation of Islamic education in School & .613 & .000 \\
\hline
\end{tabular}

*Significance at level $p<0.01$

Source: Questionnaire 2011

In addition to the correlation between variables Influence of social environment and Level of Islamic knowledge with the Level of Character internalization, this research also finds a correlation between variable Influence of social environment and Implementation of Islamic Education in school. Findings obtained show that on the whole, Influence of social environment has a very high impact on Implementation of Islamic Education in school ( $r=.613$, sig.=.000). Teachers are found to be a variable with the most influence $(r=.576$, sig.=.000) and Artistes are a variable with the least influence $(r=.119$, sig. $=.000)$ on the Implementation of Islamic Education in school. Other variables such as Influence of parents $(r=.425$, sig. $=.000)$, school environment $(r=.406$, sig. $=.000)$, the law $(r=.398$, sig. $=.000)$, the community $(r=.394$, sig. $=.000)$ and friends $(\mathrm{r}=.353$, sig. $=.000)$ are also found to contribute in ensuring smooth implementation of Islamic Education in school. Findings therefore refute hypothesis $\mathrm{H}_{0} 77$.

\section{Discussion and Conclusion}

Descriptive Findings. 42 question items are presented to evaluate the level of Character internalization of Muslim students in going about their daily routine. On the whole, only two items are at average level, while 40 other items are at a high level. This makes the overall mean for the level of Character internalization to be high. However, there is cause for some concern in terms of character building because research finds that the mean value for some of the items is below 4.00. This shows that there is still a lack of religious sensitivity in some of the students in that character internalization has not achieved $100 \%$ as is hoped for.

In addition, "I have sexual relations" should be given attention. Even though this item obtains a high mean value of 4.74 , it still does not suffice as it shows that though on a small scale, there is nevertheless a minority of students who have illicit sexual relations. It is feared that this matter will be increasingly worrisome should no preventive steps be taken. 
Pearson Correlation: Analysis of the correlation between the variable Level of Islamic knowledge and Level of Character internalization shows an average relationship between all variables. The correlation between Islamic culture and character and Level of Character internalization records the highest correlation value, followed by the correlation between the variable Tilawah al-Quran and hadith with Level of Character internalization, Aqidah (creeds) with Level of Character internalization, Seerah and Islamic civilization with Level of Character internalization, and finally between Ibadah and Level of Character internalization. On the whole, analysis shows that there is a strongly significant correlation between Islamic knowledge and the Level of Character internalization. This shows that a sound level of Islamic knowledge increases the Level of Character internalization of students.

Influence of Social Environment has a significant impact on Level of Character internalization of students. Only one variable is at a low level, namely, artistes' influence. This shows that artistes have a low influence on the building of youth character. On the other hand, Islamic Education teachers are seen as having a very high influence on the building of student character. Influence of parents, the law, the community, school environment and friends are also seen as having an influence on Level of Character internalization of respondents.

From the findings obtained, it can be concluded that the Level of Islamic knowledge and Level of Character internationalization of respondents are high and strongly corrrelated. Implementation of Islamic Education in schools is also high, while teachers and parents are seen as the most influential in building good student character. However, all these are still in need of improvement so that the objectve of Islamic Education may be fully realized.

\section{Acknowlegdement}

This study is financed by the research project on The Effectiveness of Islamic Education in Malaysia, ID: IIKH-00122011, which is funded by the National University of Malaysia.

\section{Refrences}

Abdullah Nasih Ulwan. 1995. Pendidikan Kanak-Kanak dalam Islam (Children Education in Islam). Translated by Syed Ahmad Semait. Singapore: Pustaka National.

Ab Halim Tamuri, Mohd. Yusof Hj. Othman, Ismail Ibrahim, Jawiah Dakir, Zakaria Stapa, ahmad Munawar Ismail, Shamsul Azhar Yahya \& Maheran Ismail@Ibrahim. 2012. Laporan Kajian Keberkesaan Pendidikan Islam di Malaysia (Report of the Research on the Effectiveness of Islamic Education in Malaysia). Bangi: Institute of Islam Hadhari, The National University of Malaysia.

Ab Halim Tamuri, Mohd. Yusof Hj. Othman, Jawiah Dakir, Ahmad Munawar Ismail \& Zakaria Stapa. 2013. Relegious Education and Ethical Attitude of Muslim Adolescents in Malaysia. In Mutticultural Education \& Technology Journal. Vol. 7 No. 4, 2014 pp. $257-274$.

Ary, D. Jacobs, L.C. \& Razavieh, A. 1996. Introduction to Research in education. Orlando Florida: Harcout Brace College Publication.

Asmawati Suhid. 2003. Kesesuaian Subbidang Pembelajaran Adab dan akhlak Islam KBSM Menurut Pesepktif guru. Prosiding Waca Pendidikan Islam Kebangsaan (Siri 3): Perkaedahan Pengajaran Pendidikan Islam antara Tradisi dan Inovasi.. Bangi Selangor: Fakulti Pendidikan, Universiti Kebangsaan Malaysia.

Babbie, E.R. 1992. The Practice of Social Research. Belmont. CA: Wadsworth.

Berenson, M.L. 1992. Basics Statistic: concepts and Aplication. Englewood Cliff, N.J: Prentice Hall.

Borgm W.R. \& Gall, M.D. 1979. Educational Research: an Introduction. 3rd Edition. New York; Longman.

Cates, W.M. 1990. Panduan Amali Untuk Penyelidikan Pendidikan. Traslate by Syaharum Abdullah. Kuala Lumpur; Dewan Bahasa dan Pustaka.

Cohen, L \& Morrison, K. 2000. Research Methods in Education. $5^{\text {th }}$ Edition . London: Routledge.

Cramer, Dauncan. 1998. Introducing statistic fo Social Research. London: Ruotledge.

Kemantraian Pendidikan Malaysia (Malaysian Ministry of Education). 1996. Laporan Mesyuarat Jawatan Kuasa Mengkaji Kurikulum Pendidikan Islam: Ke Arah Pembentukan dan Pengukuhan akhlak Pelajar ke-2. Kuala Lumpur: Bahagian Pendidikan Islam dan Moral, Kementerian Pendidikan Malaysia.

Ratnawati Mohd. Asyraf. 2003. Putting Statistic in its Place: Implications for Teaching in Islamic Institutions of Higher Learning. Muslim Education Quorterly 20 (1 \& 2): 13-26

Wan Hasmah Wan Mamat. 1993. Pelaksanaan Pendidikan Moral di Sekolah: Matlamat dan Harapan. Kuala Lumpur: Bahagian Pendidikan Islam dan Moral, Kementerian Pendidikan Malaysia.

Zaidatun Tasir \& Mohad Salleh. 2001. Pengenalan Kepada analisis Data Berkomputer. Kuala Lumpur: Venton Publishing.

Zakaria Kasa et al. 1996. Laporan Penyelidikan Penerapan Nilai Murni Merenta Kurikulum: Satu Kajian. Kementerian Pendidikan Malaysia dan Universiti Pertanian Malaysia.

Zakaria Kasa et al. 1996. Laporan Penyelidikan Pendidikan Akhlak di Sekolah Menengah Kebangsaan Agama. Kementerian Pendidikan Malaysia dan Universiti Pertanian Malaysia. 